\title{
Advantages and Disadvantages of Healthcare Waste Treatment and Disposal Alternatives: Malaysian Scenario
}

\author{
Maryam Khadem Ghasemi*, Rosnah Bt. Mohd. Yusuff \\ Department of Mechanical and Manufacturing Engineering, Faculty of Engineering, \\ Universiti Putra Malaysia, 43400 Serdang, Selangor, Malaysia
}

Received: 5 July 2015

Accepted: 7 September 2015

\begin{abstract}
The generation of a comparatively large amount of potentially infectious and hazardous wastes has increased in healthcare services. Worldwide inappropriate healthcare waste management practices can have a direct and indirect effect of health hazards. This article summarizes a literature review into healthcare waste and presents basic information on characteristics of them generated in healthcare centers. Also, this paper placed emphasis on sustainable treatment of the healthcare waste with case study. Different types of clinical waste include infectious, pathogenic, genotoxic, radioactive, and pharmaceutical materials, plus sharps. The various clinical wastes have to be managed and handled differently. There are several methods of healthcare treatment such as incineration, autoclaving, microwaving, landfilling, and plasma pyrolysis. Each of them has its own advantages and disadvantages. Before selecting the right treatment technology, it is necessary to substantiate the waste volume and its category. Currently, healthcare waste is generally treated by incineration technology and the incinerated ash is disposed of in Malaysian landfills. There are several constraints on incinerating and landfilling healthcare wastes as such waste can be a major source of dioxin and furan pollution that may pose such health problems as liver failure and cancer. Therefore, other potential methods should be examined as alternatives to incineration and landfilling in order to better manage healthcare waste in Malaysia.
\end{abstract}

Keywords: healthcare waste management, treatment/disposal technologies, waste generation, environmental, sustainable

\section{Introduction}

Each country has various ranges of healthcare wastes produced from healthcare services. The generation of a comparatively large amount of potentially infectious and hazardous wastes have increased in healthcare services (i.e., hospitals, clinics, laboratories, pharmacies, and other supported healthcare facilities) every year [1-3]. Each

*e-mail: maryamkhadem2009@yahoo.com type of medical waste has required its own management process and treatment [4]. Inappropriate healthcare waste management practices worldwide can have direct and indirect effects on hazards to healthcare staff and patients that include such diseases as cholera, dysentery, skin infection, and infectious hepatitis, as well as environmental pollution [5-8].

Several types of treatment and disposal process, burn and non-burn technology, are available for healthcare wastes. It is essential to comprehend the waste category and volume before adapting the treatment method 
as various categories of wastes have to be managed differently [9]. Therefore, healthcare facilities must employ cost-effective and effective treatment and disposal technologies for their clinical wastes based on the classification and characteristics of wastes to decrease volume and reduce cost as well as prevent environmental hazards and protect occupational safety $[1,10]$. Hence, many potential evaluation factors - including economical, technical, environmental, and social - must be considered to determine an appropriate healthcare waste treatment alternative for safe healthcare management [11-13]. The main objectives of this review are as follows:

1. Summarize the information of healthcare waste generation and treatment options.

2. Review the status of healthcare waste treatment in Malaysia.

3. Determine the best proper technology for the safe treatment of healthcare waste.

Thus, the present review proposes summarizing available information and definitions of healthcare waste and treatment technologies to implement the sustainable method for treatment.

Background information on the technologies is involved in order to provide information to those who may not be aware of the detail of each alternative. The majority of information gathered in our paper has been collected from the desk study of open literature survey, although some data have been obtained from reports available to the authors.

\section{Healthcare Waste (HCW)}

Healthcare activities generate an extensive amount of waste. Such wastes contain, besides domestic wastes, non-risk or general healthcare waste with a similar composition to household and municipal waste such as paper, cardboard, food wastes, glass, etc. [14]. The general wastes produced by health-care suppliers are among 75 to $90 \%$ and a wide range of clinical wastes as

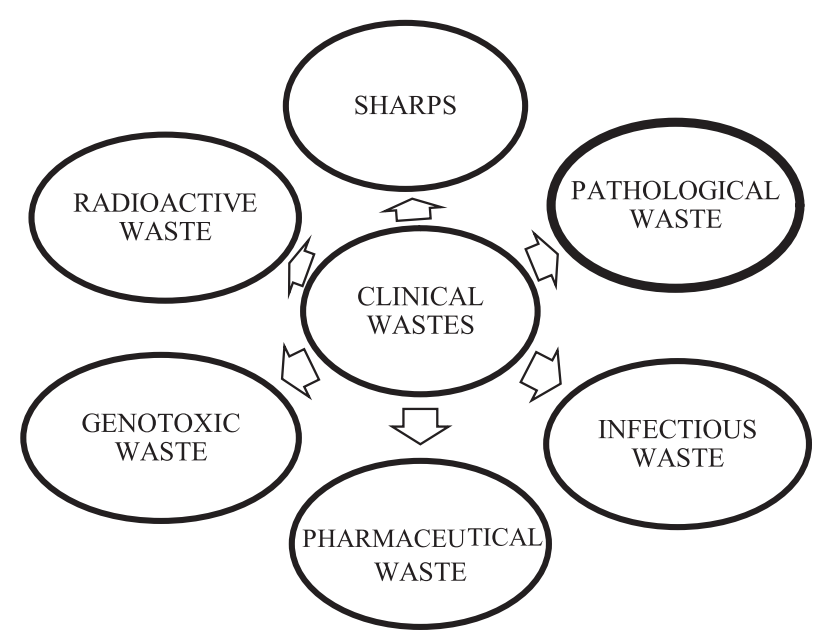

Fig. 1. The categories of clinical waste. hazardous wastes is $10-25 \%$ that may create a variety of environmental hazards and public health risks $[15,16]$. In addition, healthcare wastes can be any waste that includes blood, body fluids, human or animal tissue, excretion, pharmaceutical products, dressings or syringes, and needles or other sharp instruments. These wastes can be generated from medical, veterinary, nursing, dental, and pharmaceutical that can be hazardous and cause infection to any person coming into contact with it [17]. Different types of clinical waste may involve infectious, pathogenic, genotoxic, radioactive, and pharmaceutical materials, plus sharps (Fig. 1) [1, 8, 18-21].

The categories of $\mathrm{HCW}[22,23]$ that need to be managed with extreme care to minimize risks and other health hazards are summarized in Table 1.

\section{Treatment/Disposal Technologies}

According to WHO, for the selection of the best healthcare waste treatment technology, they must have minimal risk evaluation for waste management facilities, minimal human health impact, and minimal environmental impact, and must be cost-effective and easily implemented $[8,22]$. In addition, the treatment technologies must be able to adequately inactivate infectious micro-organisms to prevent dangers to public health and safety $[14,24-$ 26]. Furthermore, before deciding the technology to be selected for treatment of clinical waste, it is necessary to substantiate the waste volume and its category because the various clinical wastes have to be managed and handled differently [9]. Table 2 summarizes treatment procedures for clinical wastes [23, 27]. The different treatment processes, method and techniques for clinical wastes to reduce the hazards and costs are namely: incineration, autoclaving, microwaving, landfilling and plasma pyrolysis.

\section{Incineration Technology}

Healthcare waste incineration has been the major technique used worldwide for disposing of the amount of materials that are biomedical waste, including explosive materials such as polyvinyl chloride plastics, papers, and discarded items of equipment [28-30]. Also, incineration is an engineered process that is designed to treat healthcare waste that uses thermal decomposition via thermal oxidation at high temperatures between 900 and $1200^{\circ} \mathrm{C}$ to destroy the organic fraction of the waste [31]. The U.S. National Academy of Science in 2000 argued that the emission of pollutants during the incineration process is a potential risk to human health, and living or working near an incineration facility can have social, economic, and psychological effects [32].

\section{Autoclaving (Steam Sterilization)}

Autoclaving/ steam sterilization is the second most commonly used waste treatment method. An autoclave 
Table 1. Healthcare wastes: description, source, and health hazard.

\begin{tabular}{|c|c|c|c|}
\hline Category & Descriptions & Source & Health hazard \\
\hline 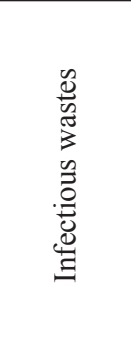 & $\begin{array}{l}\text { Consists of materials and instruments in } \\
\text { contact with humans and animals infected } \\
\text { with highly infectious agents and pathogens } \\
\text { (bacteria, viruses, parasites or fungi) that } \\
\text { pose a risk of disease transmission. }\end{array}$ & $\begin{array}{l}\text { Wastes from surgeries and autopsies } \\
\text { on patients with infectious diseases, } \\
\text { gloves, aprons; excreta, blood and } \\
\text { other body fluids and soiled materials } \\
\text { from isolation wards; dialysis } \\
\text { tubes and filters; infected animals; } \\
\text { laboratory stocks and cultures, } \\
\text { isolation wards, dialysis tubes and } \\
\text { filters. }\end{array}$ & $\begin{array}{l}\text { Viral hepatitis A, B and } \\
\text { C, anthrax, septicaemia, } \\
\text { candidaemia, bacteriaemia, } \\
\text { hemorrhagic fevers, AIDS, } \\
\text { genital infection, respiratory } \\
\text { infections, gastro enteric } \\
\text { infections, skin infection and } \\
\text { ocular infection. }\end{array}$ \\
\hline $\begin{array}{l}\stackrel{n}{\bar{z}} \\
\text { है }\end{array}$ & $\begin{array}{l}\text { Sharps are subcategory of infectious health } \\
\text { care waste that contain all objects and } \\
\text { materials that are closely connected with } \\
\text { healthcare activities and are sharp that can } \\
\text { cause risk of injury and infection due to } \\
\text { their puncture or cut property. So, sharps } \\
\text { are considered as one of the most hazardous } \\
\text { waste generated in the healthcare and they } \\
\text { must be managed with the maximum care. }\end{array}$ & $\begin{array}{l}\text { Disposable needles, hypodermic } \\
\text { needles, infusion sets, saws, broken } \\
\text { glass and pipettes, scalpels and } \\
\text { other blades, knives, syringes with } \\
\text { attached needles, auto-disable } \\
\text { syringes. }\end{array}$ & $\begin{array}{l}\text { Viral hepatitis A, B and } \\
\text { C, anthrax, septicaemia, } \\
\text { candidaemia, bacteriaemia, } \\
\text { hemorrhagic fevers, AIDS, } \\
\text { genital infection, respiratory } \\
\text { infections, gastro enteric } \\
\text { infections, skin infection and } \\
\text { ocular infection. }\end{array}$ \\
\hline $\begin{array}{l}\bar{E} \\
.00 \\
0 \\
0 \\
0 \\
0 \\
0 \\
0 \\
0\end{array}$ & $\begin{array}{l}\text { Pathological waste could be a subcategory } \\
\text { of infectious waste, but often is often } \\
\text { categorized separately in particular when } \\
\text { unusual methods of managing, treatment } \\
\text { and disposal are used. }\end{array}$ & $\begin{array}{l}\text { Pathological waste including of } \\
\text { human tissues, blood, unused blood } \\
\text { products, body fluids, body parts, } \\
\text { organs, fetuses and human flesh and } \\
\text { wastes from surgery and autopsies on } \\
\text { patients with infectious diseases }\end{array}$ & $\begin{array}{l}\text { Viral hepatitis A, B and } \\
\text { C, anthrax, septicaemia, } \\
\text { candidaemia, bacteriaemia, } \\
\text { hemorrhagic fevers, AIDS, } \\
\text { genital infection, respiratory } \\
\text { infections, gastro enteric } \\
\text { infections, skin infection and } \\
\text { ocular infection. }\end{array}$ \\
\hline 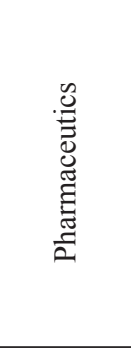 & $\begin{array}{l}\text { Pharmaceutical wastes are unused, expired } \\
\text { and polluted pharmaceutical goods, } \\
\text { proprietary drugs, no longer required } \\
\text { vaccines and sera, in addition, throw away } \\
\text { item such as vials and boxes containing } \\
\text { pharmaceutical residues, gloves, masks and } \\
\text { connecting tubing that due to their chemical } \\
\text { or biological nature, need to be disposed } \\
\text { attentively. }\end{array}$ & $\begin{array}{l}\text { Chemicals and drugs that are } \\
\text { returned from the wards, outdated, } \\
\text { spilled, no longer required or } \\
\text { contaminated. }\end{array}$ & $\begin{array}{l}\text { Intoxication, injuries and either } \\
\text { by acute or chronic exposure } \\
\text { including burns, to skin, eyes, or } \\
\text { the mucous membranes caused } \\
\text { by contact with flammable, } \\
\text { corrosive or reactive materials }\end{array}$ \\
\hline 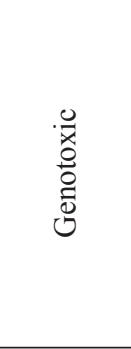 & $\begin{array}{l}\text { Genotoxic waste is extremely hazardous, } \\
\text { mutagenic inducing a genetic mutation, } \\
\text { teratogenic that cause defects in a fetus. } \\
\text { And is a cancer-causing like cytotoxic } \\
\text { drugs used in cancer treatment and the } \\
\text { metabolites. }\end{array}$ & $\begin{array}{l}\text { Out of date drugs, drugs that came } \\
\text { back from the wards, polluted } \\
\text { materials from drug procurement } \\
\text { such as gauzes, vials, syringes, } \\
\text { needles, packaging, urine, vomit } \\
\text { and faeces from patients, which may } \\
\text { have potentially hazardous amounts } \\
\text { of the administered cytostatic drugs } \\
\text { or of their metabolites. }\end{array}$ & $\begin{array}{l}\text { Nausea, headache or dermatitis, } \\
\text { dizziness, and extreme irritants } \\
\text { which have dangerous special } \\
\text { effects after through contact } \\
\text { with eyes or skin. It increases } \\
\text { earnest safety harms, both inside } \\
\text { hospitals and after disposal. }\end{array}$ \\
\hline 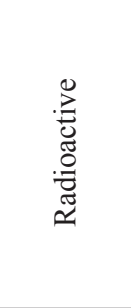 & $\begin{array}{l}\text { Materials contaminated with radionuclides } \\
\text { used in health care are in either unsealed } \\
\text { or open sources or sealed sources are } \\
\text { radioactive wastes. They are produced as } \\
\text { a result of procedures like in vitro analysis } \\
\text { of body tissue and fluid, in vivo organ } \\
\text { imaging and tumor localization, and various } \\
\text { investigative and therapeutic practices. }\end{array}$ & $\begin{array}{l}\text { Solids, gaseous and liquid wastes } \\
\text { tainted with unnecessary radioactive } \\
\text { materials used in diagnosis and } \\
\text { therapy of diseases such as toxic } \\
\text { goiter, infected glassware, urine and } \\
\text { excreta from tested with unsealed } \\
\text { radionuclides or patients treated. }\end{array}$ & $\begin{array}{l}\text { Headache, dizziness, and } \\
\text { vomiting, affect genetic material } \\
\text { and demolitionof tissue. }\end{array}$ \\
\hline
\end{tabular}

essentially is a metal vessel designed to sustain high pressures and temperatures, with a sealable door and an arrangement of pipes and hatches through which steam is introduced to and removed from the vessel. In other words, in an autoclave the process steams the waste materials to destroy potentially infectious effects and kills pathogens before entombing the wastes [3, 23]. Since autoclaves use only limited quantities of waste and for the highly infectious waste, such as microbial cultures or sharps [33], a shredder combined with an autoclave can be the 
Table 2. Suitability of treatment procedures for each type of clinical waste [23, 27].

\begin{tabular}{|c|c|c|c|c|c|c|}
\hline \multirow{2}{*}{ Type of Treatment } & \multicolumn{7}{|c|}{ Type of Clinical Wastes } \\
\cline { 2 - 7 } & Infectious & Sharps & Pathological & Pharmaceutic & Genotoxic & Radioactive \\
\hline Incineration & Yes & Yes & Yes & Yes & Yes & No \\
\hline Autoclaving & Yes & Yes & No & No & No & No \\
\hline Microwaving & Yes & Yes & No & No & Yes & Yes \\
\hline Plasma pyrolysis & Yes & Yes & Yes & Yes & No & No \\
\hline Landfilling & Yes* & Yes** & No & No & & \\
\hline
\end{tabular}

best option to treat the medical waste to reduce the size of waste that has to go to the landfill sites [34].

\section{Microwaving}

Microwave technology of clinical waste in the healthcare waste sector is considered an alternative technology of the incinerator and is a steam-based process, and electromagnetic waves with frequencies between radio and infrared waves that use wet inside the wastes or by additional steam to sterilize wastes and destroy infectious agents and pathogenic organisms in the waste. So it includes the use of high-intensity radiation to heat the moisture inside the waste $[8,35,36]$. The types of waste generally treated in microwave systems are equal to those treated in autoclaves [37]. Also, microwave methods cycle very rapidly between positive and negative and the very high frequency around 2.4 billion significant times per second that when receive the body of liquid or solid vibrate very quickly to result in friction to create significant amounts of heat [3].

\section{Landfilling}

The landfill method is one of the popular methods because all wastes after minimization or treatment need access to land for final disposal to remove the remaining healthcare waste materials with the least environmental impact. The treated waste can be disposed of in a regular municipal waste landfill with most non-incineration technologies [38]. Although the landfill method is an easy and low-cost waste disposal method, it can enhance human health risk and environmental pollution if not handled carefully and properly $[39,40]$. Furthermore, three waste products, including solid-like degraded waste, liquid-like leachate (which is water polluted with waste), and gas as landfill gas are generated from landfills that may pollute the environment. So landfills cannot be a safe method of healthcare waste treatment $[8,39]$.

\section{Plasma Pyrolysis}

Plasma pyrolysis is a modern technology for safe disposal of healthcare waste. Also, it is an environmentally friendly technology that transforms organic waste into useful products [41], and it is another type of thermal parsing of carbonaceous materials in oxygen. Plasma pyrolysis technology needs two chambers installed so that the primary chamber takes place at a high temperature of $1,100^{\circ} \mathrm{C}$ and secondary chamber ignition takes place at 950 to $1,000^{\circ} \mathrm{C}$ [42]. In addition, due to the severe heat generated by the plasma, it can dispose of all types of waste, including municipal solid waste, biomedical waste, and hazardous waste in a safe and reliable manner [33, 43].

Studies on healthcare waste treatment show that among many methods for HCW treatment, about 59$60 \%$ are treated via incineration, $37-20 \%$ by steam sterilization, and $4-5 \%$ by other treatment technologies $[1,44,45]$. Incineration methods are most used among the technologies for healthcare waste treatment in most countries. So the advantages and disadvantages of each technology are summarized in Table 3 [27, 46-48].

\section{Malaysian Scenario for Healthcare Waste Treatment}

Healthcare services are developing in Malaysia. The cost of treatment is still cheaper than in other countries in this area. Moreover, Asian patients are expected and believed to obtain a better standard of healthcare facility and treatment from Malaysian healthcare services [49, 50]. Also, the number of foreign patients who come to be treated in Malaysia is increasing every year. The increasing number of healthcare facilities and patients has produced an increase in the amount of healthcare waste. Therefore, healthcare waste management systems must operate properly.

According to the Ministry of Health Malaysia (MOH) [51], hospital waste in Malaysia contains general waste, clinical waste, pharmaceutical waste, hazardous chemicals, and radioactive waste (of which 75 to 90 percent of hospital wastes are generally), and the remaining 10 to 25 percent of the wastes are hazardous [52]. According to the scheduled waste by the Department of the Environment (DOE), the hospital waste in Malaysia in 2010 is 42,029.33 metric tons (Table 4), which with the current clinical waste growth rate, a development of accessible plants and appropriate management of healthcare wastes in Malaysia is necessary for proper treatment to reduce the adverse effects that this waste may pose [52]. 
Table 3. Comparison of treatment technologies [27, 46, 47, 48].

\begin{tabular}{|c|c|c|c|c|c|}
\hline & \multicolumn{5}{|c|}{ Treatment Technologies } \\
\hline & Incineration & Autoclave & Microwave & $\begin{array}{l}\text { Plasma } \\
\text { Pyrolysis }\end{array}$ & Landfilling \\
\hline 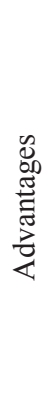 & $\begin{array}{l}\text { - Accept the greatest } \\
\text { variety of waste, } \\
\text { - Treated waste is } \\
\text { unrecognizable as ash, } \\
\text { - Significant volume } \\
\text { reduction, } \\
\text { - Energy recovery, } \\
\text { - Waste totally sterilized }\end{array}$ & $\begin{array}{l}\text { - Environmentally } \\
\text { sound, } \\
\text { - Adopted for } \\
\text { many years, } \\
\text { - No hazardous } \\
\text { emissions, } \\
\text { - Low cost, } \\
\text { - Technology } \\
\text { is easily, } \\
\text { - No pre-or-post } \\
\text { treatment required }\end{array}$ & $\begin{array}{l}\text { - Technology } \\
\text { is easy, } \\
\text { - Reduce volume } \\
\text { by } 80 \% \text {, } \\
\text { - Environmentally } \\
\text { sound, } \\
\text { - No liquid } \\
\text { effluents, } \\
\text { - The emissions } \\
\text { are minimal }\end{array}$ & $\begin{array}{l}\text { - Suitable all types of wastes, } \\
\text { - Consumes less space, } \\
\text { - Environmentally sound, } \\
\text { - Not require chimney, } \\
\text { - Toxic residuals is much below, } \\
\text { - Not require segregation, } \\
\text { - Energy recovery, } \\
\text { - Reduce volume } \\
\text { more than } 99 \%\end{array}$ & $\begin{array}{l}\text { - Low cost, } \\
\text {-Easy operation }\end{array}$ \\
\hline 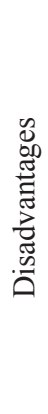 & $\begin{array}{l}\text { - Very expensive, } \\
\text { - Acid gases in air } \\
\text { emissions, } \\
\text { - Heavy metals in } \\
\text { ash residues, } \\
\text { - Convert biological } \\
\text { problem into } \\
\text { potential air quality } \\
\text { emission problems, } \\
\text { - Major source of dioxin } \\
\text { and furan emissions }\end{array}$ & $\begin{array}{l}\text { - Need drying } \\
\text { mechanism, } \\
\text {-Foul odors, } \\
\text { - Not suitable for all } \\
\text { types of wastes, } \\
\text { - Need a shredder to } \\
\text { reduce the volume }\end{array}$ & $\begin{array}{l}\text { - Cost is very high, } \\
\text { - Not suitable } \\
\text { for all types } \\
\text { of wastes, } \\
\text { - The shredder } \\
\text { used is noisy } \\
\text { - Offensive odors }\end{array}$ & $\begin{array}{l}\text { - Requires technical persons, } \\
\text {-Cost is very expensive }\end{array}$ & $\begin{array}{l}\text { - Requires access } \\
\text { to sanitary } \\
\text { landfill, } \\
\text {-Cause soil } \\
\text { pollution, } \\
\text { - water } \\
\text { contamination, }\end{array}$ \\
\hline
\end{tabular}

Table 4. Clinical waste generation in Malaysia 2004-10 in metric tons/year.

\begin{tabular}{|c|c|c|c|c|c|c|c|}
\hline Year & 2004 & 2005 & 2006 & 2007 & 2008 & 2009 & 2010 \\
\hline $\begin{array}{c}\text { Clinical waste generation } \\
\text { in Malaysia (MT/y) }\end{array}$ & 80,076 & 37,508 & 31,847 & 17,743 & 26,968 & 94,602 & 42,029 \\
\hline
\end{tabular}

Up to the 1980s, Malaysia had no appropriate management of clinical waste. Due to increases of HIV, the Ministry of Health $(\mathrm{MOH})$ along with the DOE prepared new policies and guidelines for management of clinical waste and control of infectious disease [53]. The DOE has regulated the Waste Pollution Prevention and Control Law and/or the regulations on medical hazardous waste management. Management and disposal of clinical waste in Malaysia using the "cradle -to- grave" concept is controlled by Environmental Quality (Schedule Waste) Regulation 1989, Environmental Quality (Prescribed Premises) (Scheduled Wastes Treatment and Disposal Facilities) Regulations 1989, and Environmental Quality (Prescribed Premises) (Scheduled Wastes Treatment and Disposal Facilities) Order 1989 [54]. Since 1993, under the privatization program in Malaysia, three private consortia have been nominated by the government to provide storage, collection, transportation, treatment, and disposal services for clinical wastes from hospitals [55], including:

- Faber Medi-Serve SdnBhd for the states of Perlis, Kedah, Penang, Perak, Sabah, and Sarawak

- Radicare (M) SdnBhd for Wilayah Persekutuan Kuala Lumpur and Putrajaya, Selangor, Pahang, Kelantan, and Terengganu
- PantaiMedivestSdnBhd for Negeri Sembilan, Melaka, and Johor [56]

In Malaysia, incineration technology and the disposal of the incinerated ash to landfills is mostly used to treat healthcare waste [9, 57]. The Bukit Nanas Integrated Waste Treatment Facility is the first general incineration treatment system in the country containing different facilities with high temperature, physical, and chemical treatments. Pursuant to the Consumers' Association of Penang (CAP), five regional medical waste incinerators were manufactured with capacity of 20 to $500 \mathrm{~kg}$ per hour to manage biomedical wastes of all types. Table 5 summarizes specification of the incinerator. Furthermore, other regions of higher capacity of about $200 \mathrm{~kg}$ per hour are in progress but still have siting problems and opposition from local authorities [55]. Nevertheless, in some of the biggest states, individual hospitals have fixed on-site incinerators for the disposal of clinical wastes [58].

According to research carried out by Omar et al. [50] in three district hospitals located in Johor, Perakand Kelantan, the infectious waste was first filled into light blue bags for autoclave treatment before placing them into yellow bags for incineration. However, all collected clinical waste has been transported to the incinerator plant and turned into ash. In addition, cities have pursued controlled and 
Table 5. Incinerator specifications.

\begin{tabular}{|c|c|}
\hline Operation time & $24 \mathrm{~h}$ \\
\hline Type of fuel & Diesel \\
\hline Type of feed & Hospital waste \\
\hline Treatment capacity & $500 \mathrm{~kg} / \mathrm{h}$ \\
\hline Amount of flue gas & $20,000 \mathrm{~m}^{3} / \mathrm{h}$ \\
\hline Amount of slag produced & $10 \%$ \\
\hline Temperature in Primary Chamber & $950^{\circ} \mathrm{C}$ \\
\hline Temperature in Secondary Chamber & $1,200^{\circ} \mathrm{C}$ \\
\hline
\end{tabular}

sanitary landfilling to receive hazardous waste [59]. At the present, the state of Selangor is using a private-sector landfill and the federal government is arranging to expand this scheme nationally. Also, the federal government constructed nine sanitary landfills between 1995 and 2000 and later improved other 27 in 34 local authorities [55].

Although there is a healthcare waste management system in Malaysia, several obstacles and problems have been found through the different studies. Also, there has not been comprehensive research and strategy done on the effectiveness of healthcare waste management for infectious disease prevention. Razali and Ishak [53] have found several problems in healthcare waste management (HCWM), one of which is the lack of enough space to wash and dry bins. Disposal cost also is increasing due to public awareness, which is measured as low to separate clinical waste and general waste. In general, fund limitations, shortage of technical knowledge, and competence, lack of storage, and insufficient transfer stations also are presented to the problem of effective healthcare waste management (EHCWM) in Malaysia [58]. Financial constraints and lack of community involvement and participation hamper implementing and improving sustainable waste management. In some countries there is an encouraging attitude to increase monetary resources and manpower abilities and capabilities for waste management services. However, at present waste management in Malaysia is similar to many countries because of parallel and overlapping tasks [59].

Healthcare wastes consist of various hazardous material combinations such as radioactive materials, toxic chemicals, and bio-hazardous factors. Thus, selecting methods of treatment for multi-hazardous wastes and determining the most proper system of treatment processes is often a complex and problematic mission in Malaysia [60].

\section{Results and Discussion}

Medical wastes involve multiple types of noninfectious waste and infectious waste of medical waste $[8,61]$. In Malaysia, the amount of wastes generated in healthcare is extensive and increasing due to pandemics such as SARS and avian flu, and outreaching health tourism in addition to seeking medical help with more people via changing demographic lifestyles and aging nations [55]. By 2020 it is predicted that medical waste from Malaysian healthcare will reach 33,000 tons annually [55]. So, with the current clinical waste growth rate, the development of a reasonable system and appropriate management of healthcare wastes in Malaysia is necessary. To select and determine the most suitable treatment method is often a problematic task in Malaysia [60]. Incineration, landfill, and autoclave methods are all used for treating clinical wastes in Malaysia.

Incineration technology has been accepted and adopted as an effective method in this country. However, the capacity of incineration is inadequate to process 18,000 tons of waste per year [55]. Also, incineration of healthcare waste can produce secondary waste and pollutants if the treatment facilities are not appropriately constructed, designed, and operated. It can be one of the major sources of toxic substances, such as polychlorinated dibenzo-pdioxins/dibenzofurans (PCDD/ PCDF), polyvinyl chloride (PVC), hexachlorobezene and polychorinated biphenyls, and dioxins and furans that are known as hazardous pollutants. These pollutants may have undesirable environmental impacts on human and animal health, such as liver failure and cancer [31, 62]. Furthermore, incineration of clinical waste is an improper technology for most developing countries because of high financial startup costs and the occupational capital essential to implementing incineration facilities $[5,6,8$, $25,63]$. Based on research conducted by Razali and Ishak [53] in Selangor hospitals, one of the major challenges of handling healthcare waste in Malaysia is an alternative treatment for incineration in the future regarded to increase in clinical waste.

Landfilling is an easy and low-cost waste disposal method. Also, it may be said that the toxic wastes produced by healthcare are significantly low, as they are separately treated via landfill. However, the site of landfilling generates air pollution and intussuscepts vermin and other disease-causing germs. Moreover, it produces waste products in three phases, namely solid, contaminated water and toxic liquid called leachate, and gas by releasing heavy metals and toxic materials like dioxins and furans into the atmosphere and that may impact and pollute the environment $[39,64]$. So a landfill is not a safe solution to treatment of clinical waste [40]. These must be taken into consideration with stringent policy to tackle the future occurrence of diseases that may affect the surrounding environment and human health [55].

Autoclaving as a non-incineration technology of healthcare waste is an alternative method to incineration. It is viewed as a more costly technology than incineration $[30,65]$. However, the autoclave method is not suitable for all kinds of clinical wastes and large amounts of hazardous waste [1]. Therefore, selecting the effective $\mathrm{HCW}$ treatment alternative and considering the need of multiple conflicting criteria problems such as economical, technical, environmental, and social, and their related sub-criteria with the involvement of a group of experts. 
It is viewed as a complex multi-criteria decision making (MCDM) problem [1, 3, 13, 66].

\section{Conclusions}

All steps in the medical waste management system are important parts of a hospital waste management operation. Medicalwasteneeds special care in its treatmentand disposal because of its hazardous and diverse characteristics. It is well known that these wastes may cause a potential hazard to human health in terms of growth of diseases by viruses and micro-organisms, and for the environment (soil, air, water) when inappropriately handled, treated, stored, transported, or disposed of. Healthcare wastes are categorized according to their source; typology and risk factors related with their managing, storage, and use of different disposal and treatment methods. There are two types of treatment technologies: incineration and nonincineration. Many non-incineration methods include autoclaving (steam sterilization), microwaving, land filling, and plasma pyrolysis. However, the final selection of the best treatment system should be made carefully, on the foundation of different factors, many of which rely on local conditions. It is a fact that incineration is the main disposal method of medical waste in Malaysia. Also, in recent years in this country, the quantity of medical waste generation and the public concerns about the inappropriate treatment and disposal of medical waste has been increased. Therefore, the Malaysian government must consider regulating policy programs and healthcare waste strategies more systematically and stringently to control cost and manage healthcare waste appropriately, as it can reduce the hazards and risks to the community and the ecosystem. Finally, other potential treatment technologies must be examined as alternatives to incineration in order to better manage medical waste in Malaysia.

\section{References}

1. LEE B. K., ELLENBECKER M. J., MOURE-ERSASO R. Alternatives for treatment and disposal cost reduction of regulated medical wastes. Waste Manage. 24 (2), 143, 2004.

2. MISRA V., PANDEY S. Hazardous waste, impact on health and environment for development of better waste management strategies in future in India. Environ Int. 31 (3), 417, 2005.

3. DIAZ L., SAVAGE G., EGGERTH L. Alternatives for the treatment and disposal of healthcare wastes in developing countries. Waste Manage. 25 (6), 626, 2005.

4. MARINKOVIC N., VITALE K., HOLCER N. J., DZAKULA A., PAVIC T. Management of hazardous medical waste in Croatia. Waste Manage. 28, 1049, 2008.

5. COKER A., SANGODOYIN A., SRIDHAR M., BOOTH C., OLOMOLAIYE P., HAMMOND F. Medical waste management in Ibadan, Nigeria: Obstacles and prospects. Waste Manage. 29 (2), 804, 2009.

6. SAWALEM M., SELIC E., HERBELL J. D. Hospital waste management in Libya: A case study. Waste Manage. 29 (4), 1370, 2009.
7. PATWARY M. A., O'HARE W. T., STREET G., MAUDOOD ELAHI K., HOSSAIN S. S., SARKER M. H. Quantitative assessment of medical waste generation in the capital city of Bangladesh. Waste Manage. 29 (8), 2392, 2009.

8. HOSSAIN M. S., SANTHANAM A., NIK NORULAINI N. A., OMAR A. K. Clinical solid waste management practices and its impact on human health and environment-A review. Waste Manage. 31 (4), 754, 2011.

9. PREM ANANTH A., PRASHANTHINI V., ISVANATHAN C. Healthcare waste management in Asia. Waste Manage. 30 (1), 154, 2010.

10. KATOCH S. S. Investigations on common treatment technologies for some biomedical wastes. Department of Chemical Engineering Thapar, University of India. India, 2008.

11. DURSUN M., KARSAK E.E., KARADAYI M. A.A fuzzy multi-criteria group decision making framework for evaluating health-care waste disposal alternatives. Expert Syst. Appl. 38 (9), 11453, 2011a.

12. DURSUN M., KARSAK E. E., KARADAYI M. A. Assessment of health-care waste treatment alternatives using fuzzy multi-criteria decision making approaches. Resour. Conserv. Recy. 57, 98, 2011b.

13. LIU H.C., WU J., LI, P. Assessment of health-care waste disposal methods using a VIKOR-based fuzzy multi-criteria decision making method. Waste Manage. 33, (12), 2744, 2013.

14. TSAKONA M., ANAGNOSTOPOULOU E., IDARAKOS E. Hospital waste management and toxicity evaluation: a case study. Waste Manage. 27 (7), 912, 2007.

15. HAMODA H.M., EL-TOMI H.N., BAHMAN Q.Y. Variations in hospital waste quantities and generation rates. J. Environ. Sci. Health., Part A. 40 (2), 467, 2005.

16. CHAERUL M., TANAKA M., SHEKDAR A.V. Resolving complexities in healthcare waste management: a goal programming approach. Waste Manage. Res. 26 (3), 217, 2008.

17. CHANDRAPPA R., DAS D.B. Solid waste management, environmental science and engineering, DOI: 10.1007/9783-642-28681-0_2, Springer-Verlag Berlin Heidelberg, 2012.

18. KUO H.W., SHU S.L., WU C.C., LAI J.S. Characteristics of medical waste in Taiwan. Water, Air, Soil Poll. 114 (3-4), 413, 1999.

19. ALTIN S., ALTIN A., ELEVLI B., CERIT, O. Determination of hospital waste composition and disposal methods: a case study. Pol. J. Environ. Stud. 12 (2), 251, 2003.

20. WORLD HEALTH ORGANIZATION (WHO). Management of waste from injection activities at the district level. Geneva, 2006.

21. MOHAMED L.F., EBRAHIM S.A., AL-THUKAIR A.A. Hazardous healthcare waste management in the Kingdom of Bahrain. Waste Manage. 29 (8), 2404, 2009.

22. PRÜSS, A., GIROULT, E., RUSHBROOK, P. Teacher's Guide: Management of wastes from health-care activities. World Health Organization (WHO), Geneva, 1999.

23. PRÜSS A., EMMANUEL J., RUSHBROOK P., ZGHONDI R., STRINGER R., PIEPER U. Safe management of wastes from health-care activities: Second edition. World Health Organization, Geneva, 2013.

24. SALKIN I.F. Conventional and alternative technologies for the treatment of infectious waste. J. Mater. Cycles Waste Manage. 5 (1), 0009, 2003.

25. NEMATHAGA F., MARINGA S., CHIMUKA L. Hospital solid waste management practices in Limpopo Province, South Africa: A case study of two hospitals. Waste Manage. 28 (7), 1236, 2008. 
26. PARK H., LEE K., KIM M., LEE J., SEONG S.Y., KO G. Detection and hazard assessment of pathogenic microorganisms in medical wastes. J. Environ. Sci. Health., Part A. 44 (10), 995, 2009.

27. EL HAGGAR S. Sustainable industrial design and waste management: cradle-to-cradle for sustainable development. Elsevier Academic Press, USA, 2010.

28. LEE K. H., CHO S.H., HONG Y.C., LEE K.H., KWAN H. J., CHOI I., KANG, D. Urinary PAH metabolites influenced by genetic polymorphisms of GSTM1 in male hospital incinerator workers. J. Occup. Health. 45 (3), 168, 2003.

29. LEE W.J., LIOW M.C., HSIEH L.T., CHEN T.J.H., TSAI P.J. Impact of polycyclic aromatic hydrocarbon emissions from medical waste incinerators on the urban atmosphere. J. Air Waste Manage. Assoc. 53 (9), 1149, 2003b.

30. JANG Y.C., LEE C., YOON O.S., KIM H. Medical waste management in Korea. J. Environ. Manage. 80 (2), 107, 2006.

31. SINGH S., PRAKASH V. Toxic environmental releases from medical waste incineration: a review. Environ. Monit. Assess. 132 (1-3), 67, 2007.

32. MOCHUNGONG P.I.K. Environmental exposure and public health impacts of poor clinical waste treatment and disposal in Cameroon. Institute for Public Health, University of Southern Denmark. Denmark, 2011.

33. KATOCH S.S. Biomedical waste classification and prevailing management strategies. In Proceedings of the International Conference on Sustainable Solid Waste Management 5-7, 2007.

34. ARMSTRONG B.A., REINHARDT P.A. Managing laboratory biomedical waste using a large on-site autoclave -shredder. J. Chem. Health Safety. 17 (6), 33, 2010.

35. ECOACCESS ENVIRONMENTAL LICENSES AND PERMITS. Clinical or related waste treatment and disposal. http://www.epa.qld.gov.au/publications/p00783aa.pdf/ Clinical_or_related_waste_treatment_and_disposal.pdf. 2006.

36. HARBEC S. The uptake of sustainable waste management: the case of electronic medical equipment, Department of Mathematics and Iindustrial Engineering, Polytechnic School of Montreal. Canada, 2009.

37. DEVINE A., et al. Testing the efficacy of a combination of microwave and steam heat for log reduction of the microbial load following a simulated poultry mass mortality event. Appl. Biosaf. 12 (2):79, 2007.

38. ÖZKAN A. Evaluation of healthcare waste treatment/ disposal alternatives by using multi-criteria decision-making techniques. Waste Manage. Res. 31 (2), 141, 2013.

39. BUT T.E., LOCKLEY E., ODUYEMI K.O.K. Risk assessment of landfill disposal site-state of art. Waste Manage. 28, 952, 2008.

40. NARAYANA T. Municipal solid waste management in India: From waste disposal to recovery of resources? Waste Manage. 29 (3), 1163, 2009.

41. INABA T., IWAO T. Treatment of waste by DC arc discharge plasmas. IEEE. Dielectr. Electr. Insul. 7 (5), 684, 2000.

42. TANKSALI A. S. Management of Bio Medical waste. Int. J. ChemTech. Res. 5 (3), 1213, 2013.

43. VYAS D. S., DAVE U. B., PAREKH H. B. Plasma pyrolysis: an innovative treatment to solid waste of plastic material. In: National conference on recent trends in engineering \& technology, NCRTET, Gujarat, 2011.

44. PARK H.S., JEONG J.W. Recent trends on disposal technologies of medical waste. J. Korea. Soc. Waste. Manag. 18 (1), 18, 2001.

45. HYLAND R.G., DRUM D.A., BULLEY M. Disposal medical wastes. In: 87th Annual Meeting and Exhibition, Air \& Waste Manage. Assoc., Paper No. 94-RP-123B.02, Cincinnati, OH, 19-24 June, 1994.

46. HCWH (HEALTHCARE WITHOUT HARM). Nonincineration medical waste treatment technologies in Europe: A resource for hospital administrators, facility managers. Health Care Professionals, Environmental Advocates, and Community Members, Washington, DC, USA (accessed online at www.noharm.org/ nonincineration), 2004.

47. USAID (U.S. AGENCY FOR INTERNATIONAL DEVELOPMENT). Environmental guidelines for smallscale activities in Africa (EGSSAA), Chapter 15: Solid waste: generation, handling, treatment and disposal. (Accessed online at www.encapafrica.org). 2009.

48. NEMA S.K., GANESHPRASAD K.S. Plasma pyrolysis of medical waste. Curr. Sci. 83 (3), 271, 2002.

49. CHEE H.L. Medical tourism in Malaysia: international movement of healthcare consumers and the commodification of healthcare. ARI Working Paper No. 83, 1, 2007. Electronic copy available at: $\mathrm{http} / / / \mathrm{ssrn}$. com/abstract $=1317163$

50. POCOCK N.S., PHUA K.H. Medical tourism and policy implications for health systems: a conceptual framework from a comparative study of Thailand, Singapore and Malaysia. Global Health, 7 (1), 12, 2011.

51. MINISTRY OF HEALTH MALAYSIA (MOH). Healthcare waste status report. Putrajaya: Engineering Services Division, Ministry of Health Malaysia. Malaysia, 2009.

52. OMAR D., NAZLI S.N., KARUPPANNAN S. A. Clinical waste management in district hospitals of Tumpat, Batu Pahat and Taiping. Procedia Soc. Behav. Sci. 68, 134, 2012.

53. RAZALI S.S., ISHAK M.B. Clinical waste handling and obstacles in Malaysia. J. Urban Environ. Engng. 4 (2), 47, 2010.

54. IBRAHIM Z.B. Management and disposal of clinical waste (case study: hospital Universiti Kebangsaan Malaysia) (Doctoral dissertation, Universiti Teknologi Malaysia). Malaysia, 2005.

55. AMBALI A.R., BAKAR A.N., MERICAN F.M. Environmental policy in Malaysia: biomedical waste, strategies and issues. Admin. Sci. 10 (1), 1, 2013.

56. KHANEHZAEIG., ISHAK M.B., MANAF L., ABDULLAH A. Clinical Waste Segregation: Towards Implementation and Obstacles in Malaysian Private Clinics. IOSR J. Environ. Sci. 8 (10), 22, 2014.

57. AZNI I., KATAYON S., RATNASAMY M., JOHARI M. M. N. M. Stabilization and utilization of hospital waste as road and asphalt aggregate. J. Mater. Cycles Waste Manage. 7 (1), 33, 2005.

58. AMBALI A. R., BAKAR A. N. Medical waste management in Malaysia: Policies, strategies and issues. In Humanities, Science and Engineering (CHUSER), 2012 IEEE Colloquium on 672, 2012.

59. TIONG C. S., PUZIAHA.L, KARUPPANNANA. L. Medical waste management in private medical clinics Taiping, Perak. Paper presented at International Conference on Ecological, Environmental and bio-Science ICEEBS'2012), April, 1315, Pattaya, 2012

60. LIM M. Measuring waste in Malaysia: A neglected approach. J. Asian Behavior. Stud. 1 (1), 41, 2011.

61. MIYAZAKI M., UNE H. Infectious waste management in Japan: A revised regulation and a management process in medical institutions. Waste Manage. 25, 616, 2005.

62. VESILIND P.A., WORRELL W.A., REINHART D.R., VESILIND A. Solid waste engineering: Brooks/Cole Pacific Grove, 2002. 
63. BLENKHARN J.A backward step: landfill disposal of clinical wastes. Journal of Hospital Infection. 63 (1), 105, 2006.

64. BLENKHARN J.I. Medical wastes management in the south of Brazil. Waste Manage. 26 (3), 315, 2006.

65. AL-KHATIB I.A., SATO C. Solid health care waste management status at health care centers in the West Bank -Palestinian Territory. Waste Manage. 29 (8), 2398, 2009.

66. ROGERS D.E., BRENT A.C. Small-scale medical waste incinerators-experiences and trials in South Africa. Waste Manage. 26 (11), 1229, 2006. 
